\title{
Between debt and the devil: beyond the normalization delusion
}

\author{
Lord Adair Turner ${ }^{1}$
}

Received: 11 December 2017/Accepted: 15 December 2017/Published online: 1 February 2018

(C) National Association for Business Economics 2018

\begin{abstract}
Since 2008, we have found it incredibly difficult to achieve adequate nominal demand growth. I think a fundamental reason we found it so difficult focuses on debt overhangs, if we first allow private leverage to grow too high, we end up in a situation where the debt doesn't go away, it just moves around the global economy. Total global debt to global GDP is now higher than it ever was before. When interest rates are already low, further reductions of interest rates have very little influence on investment and consumption. Ultra-loose monetary policy does produce increases in asset prices. But if that's driving an increase in inequality on top of slow growth of real wages. There has been inadequate focus in economics on the different functions that credit creation plays within the economy. We have to think about control of the credit cycle as an end, per se. Our orthodoxy before the crisis was that private credit and money creation is just fine. We have to understand that both governments can fail and be dangerous, and that markets can fail and be dangerous.
\end{abstract}

Keywords Debt overhangs - Monetary policy - Credit creation - Low interest rates $\cdot$ Leverage

Good morning, ladies and gentlemen. It's a great pleasure to be here speaking at the National Association for Business Economics. Some of you may have been here 3 years ago, where I also spoke at a NABE Conference, though I think that was in Chicago, not in Cleveland.

Speech delivered at the NABE annual meeting, September 25, 2017.

Lord Adair Turner

lina.morales@inetneconomics.org

1 Institute for New Economic Thinking, New York, USA
Those of you who were there may have noted that I'm a somewhat lazy person. Because the title that I have for today's speech is "Between Death and the Devil, Beyond the Normalization Delusion." The title that I had when I spoke 3 years ago was, "Central Banking After the Crisis, no Return to Past Certainties." So, it's rather a similar theme.

But I'm going to be unapologetic about that, because although like Keynes, "I believe that if the facts change, I'll change my mind," I don't think the facts have changed. I think now, as in 2014, the fundamental fact of the global economy, at least in the advanced economies, is that we're living in very strange times. And that we are far from out of the problems created by the crisis of 2007-2008.

Now, of course, there's a lot of discussion these days about normalization, about exit. The Fed's statement last week was about shrinking the balance sheet. Janet will talk about that here tomorrow). The ECB is talking about maybe beginning to taper the pace of its purchases by next year. We're talking about higher interest rates-they've begun already, to some extent, here in the U.S.—but perhaps beginning in other countries as well.

But I think if you step back, the big picture is still just how extraordinarily low interest rates are 10 years after the crisis began, and what an extraordinary small impact they've had on growth and inflation. Just ask yourself, if somebody had told you in 2009, after you had come through the crisis itself, in January 2009, and said, "I can see the future. In 2017, U.K. interest rates will be a quarter, the ECB interest rates will be negative, Japan, zero, and the U.S., 1\%. They'll have been like that for 8 years. What do you think the rate of inflation will be?"

You'd have thought, oh my God, the central banks have gone mad. There'll be hyper-inflation. But in fact, we have central banks struggling, still struggling, to achieve even 
the inflation targets they've set. The big story is a story of continually disappointed expectations of a return to normality.

Figure 1 shows, from a series of Bank of England inflation reports, the forward curve for interest rates. Back in 2009, we thought we'd be back at normality within 6 months or a year. In 2010, and then again in 2011 and 2012 we thought, well, it's going to take a bit longer. But slowly and slowly, the expectations got disappointed. Although we are seeing interest rates rising now in the U.S., here's my prediction: I don't think in 2020 in the U.S. they're going to be above, say, $2.5 \%$. I think in the U.K. they won't be above $1 \%$. I think in the ECB and Japan, they'll be pretty much where they are at the moment: somewhere about zero.

I think we are in very strange times. You see that also in long-term interest rates. Over the last week, U.S. 10-year yields have edged up from 2.13 to about 2.26. But that's still not a return to anything like the sort of 10 -year yields we used to see.

If you look at real yields, this is the really extraordinary story. The real yield to maturity on a ten-year index-linked gilt (similar to that on a U.S. Treasury bond), has been in a relentless decline, not just after the crisis, but for about 30 years. Think about this, think about the weird world we live in. The Swiss government will now give you a 50-year bond which involves this absolutely copper-bottom guarantee. Give them 1000 Swiss francs today and in 50 years' time, they will give you back slightly less than 1000 francs in real terms. The Swiss government guarantees that. This isn't how economics is meant to work.

And look at the rate of growth that we've been achieving. We used to believe that advanced economies would typically grow at maybe $1.5-2 \%$ per capita per annum. Of course, they wouldn't grow as fast as emerging economies. But we thought that rate was the model.

But over the last 10 years, 2007-2016, even the U.S., which has done the best, has grown only $0.5 \%$ per capita per annum. You see lower figures still for the U.K., and almost zero for the Eurozone. It should not surprise us that we then get very strong populist political reactions across the world in various forms. We saw one of those last night in Germany.

By 2020, there is going to be no recovery of lost ground. Look at the FOMC's latest forecast. They don't suggest that after this loss of a decade, there will be a recovery. They see the economy growing at $1.8,1.9 \%$, for the next 3 years. In 2020, even here in the U.S., GDP will be some $10-15 \%$ below where it would've been on pre-crisis trend. There will be a much bigger loss in other countries. So, the question is, why was there in 2007-2008 this extraordinary break in the success of capitalism?

Part of the reason may be that the growth rates before 2007-2008 were fooling us. That they were, as it were, swollen by some things that had gone into calculated GDP which weren't really there. The more that I look into it, the
Fig. 1 Successive market forecasts of the Bank of England interest rates

\section{Successive market forecasts of BofE interest rates}

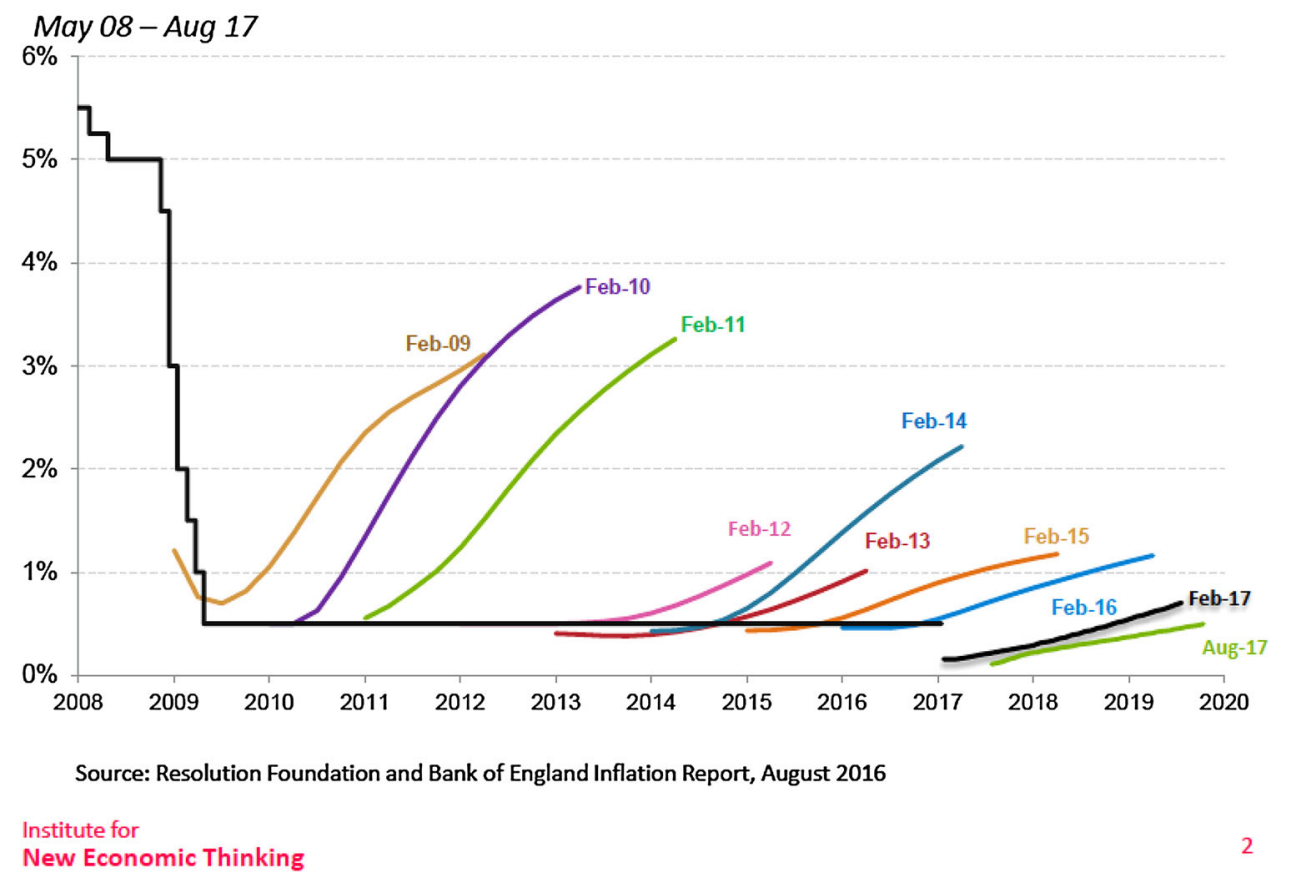


more I lack confidence in what some of our G.D.P. and productivity figures mean. It may be that part of what's been going on is what Robert Gordon describes as a set of supply-side factors, which are headwinds against the rate of potential productivity and G.D.P. growth-and that those factors were at work pre-2007 but hidden by other factors (such as some financial activity) artificially swelling estimated GDP.

But part of the problem has undoubtedly been that since 2008 we have found it incredibly difficult to achieve adequate nominal demand growth. If you believe that the real economy can grow at $1.5-2 \%$ per annum and if you think you want to hit a target rate of inflation of $2 \%$, then you have to have aggregate nominal demand, nominal GDP, growing at about $3.5-4 \%$. But, basically, all the governments and central banks of the world have failed to do that. All of the advanced economies have failed to do that over the last 7 years. So, we have to ask, why has it been so difficult to get an adequate rate of growth of nominal demand?

I think there are two major hypotheses out there. I'm only going to talk now about one of them. The second of them is the one that Larry Summers has put forward on secular stagnation (I'm actually quite convinced by Larry's assertion).

But, in the interest of time, and because it is the major focus of my book, which is now out in paperback (and which, by the way, happens to be called Between Death and the Devil), let me run through why I think a fundamental reason we found it so difficult to grow nominal demand focuses on debt overhangs, and what that implies not just for policy, but for some of the fundamental issues of economic theory.

If I had to set out one chart which I think, sums up why it has been so difficult for us to achieve recovery from 2008, it would be this chart (Fig. 2), which is taken from Ken Rogoff and Carmen Reinhart's great work (Reihart

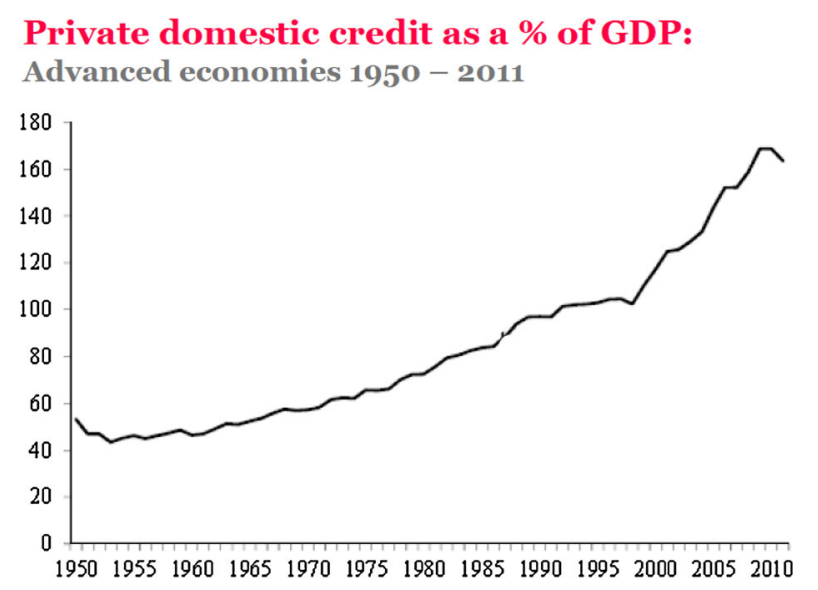

Source: Financial and Sovereign Debt Crises: Some Lessons Learned and Those Forgotten, C. Reinhart \& $\mathrm{K}$. Rogoff, 2013

Fig. 2 Private domestic credit in advanced economies as a percentage of GDP (1950-2011) and Rogoff 2013), on long-term debt. What it shows is private, domestic credit, so has nothing to do with governments. This is private credit, households and companies, as a percent of all GDP for all the advanced economies together from 1950 to 2007. As you can see it grew from $50 \%$ in 1950 to $170 \%$ in 2007 . It grew pretty much every year throughout that period. Now what's interesting is that as that growth occurred, it actually produced relatively little concern among policymakers or academic economists. Indeed, there was a lot of academic work and policy on how to ensure we achieved adequate credit growth. But very little focus on, once you've had credit growth growing faster than nominal GDP for a long period of time, should you be worried about the level of leverage?

Actually, it's interesting that that insouciance, that lack of attention, could have been legitimate, if two things that we tend to say about credit and banks were true. If you were to pick up most of our economic textbooks or a lot of advanced academic papers, and look there at the description of what the banks do, and you'll find they tend to say two things. First, that banks take deposits of money, apparently pre-existing money, from savers, and they lend it on to borrowers. And secondly, that they lend that money to entrepreneurs and businesses, and thus allocate funds between alternative investment projects. That's, broadly speaking, what we are still teaching undergraduates today.

But, as a description of what modern banks do in modern economies, this is pretty much entirely fictional. These textbooks, in respect to those statements, should be on the same shelves of the book shelf as Harry Potter. They're just not correct.

Why do I say that? Because banks do not just take in pre-existing money; instead banks create credit, money, and purchasing power that did not previously exist. That great insight, which is there in a lot of the early 20th century economists like Knut Wicksell in particular, is fundamental to the Austrian school of Frederick von Hayek. It's there in Keynes, though more in the Treatise on Money than in The General Theory. This great and fundamental insight was, I think, tragically, something that we moved away from in most mainstream economics after about the 1960s and 1970s.

The second way that these statements are fictional is the idea that banks lend money to entrepreneurs and businesses, and thus allocate funds between alternative capital investment projects. They can do that, but actually modern banks in modern economies primarily don't do that. What they primarily do is lend money against real estate, and primarily against real estate that already exists.

There a great piece of work done by Òscar Jordá, Moritz Schularick, and Alan Taylor called "The Great Mortgaging," along with other papers that they produced, which has been funded by INET, the institute which I chair. They 
have looked, over a 130-year period, at what banks actually do. In particular, at how much money they lend, how much of their loan book is lent, against real estate.

The big picture has been summed up by those authors themselves. It's this: "With very few exceptions, banks' primary business did indeed consist of non-mortgage lending to companies in 1928-[just before the crash]-and up to 1970. But by 2007, banks in most countries had turned primarily into real estate lenders. The intermediation of household savings for productive investment in the business sector, which is the standard textbook role of the financial sector, constitutes only a minor share of the business of banking today." If we don't understand that, I don't think we can really understand what occurred in 2007-2008 and why it has been so difficult to recover from it.

The reason why this matters was crucially understood by Hyman Minsky, an economist who was largely and tragically ignored in the years before the crisis. It's this: when what you do is you lend money against real estate, and if the land on which that real estate is at least in the shortterm in limited supply (so that you can't rapidly create more central Manhattan, more central San Francisco, more central London, more central Paris), then the only thing that will give in the short-term is the price. The increase in the asset price of property will unleash expectations and behavioral attitudes on the behalf of both lenders and borrowers, which will lead them to lend and borrow more money, which will drive the cycle around. The cycle will go around, and around, and around, in an upswing until it produces a crisis, and then a downswing.

Work by Claudio Borio of the Bank for International Settlements has clearly shown that these cycles of real estate lending and asset prices are not just part of the story of financial and macroeconomic instability in modern economies, they are, again and again, pretty much the whole story.

The problem is that if the switch from upswing to the downswing occurs once we already have a very high level of leverage, we enter an environment where the debt doesn't go away, it simply moves around the global economy. We ought to have known that that might occur, because we had a canary in the mine. The canary was called Japan. In the late 1980s, as we all know, Japan had a huge credit and asset price bubble that drove property prices in Tokyo to enormous high levels. The bubble cracked, burst in 1990, and we swung into a downswing of falling credit demand and falling asset prices.

What then occurred was a long, slow period in which non-financial corporations (in Japan it was primarily companies who had borrowed, not residential households) were determined to pay down their debt. They were determined to pay down that debt even when the Bank of
Japan cut interest rates to zero. That attempted debt repayment drove the economy into recession and in that recession public deficits went up. Those public deficits provided a useful stimulus to demand, and without them Japan would have suffered a real 1930s style depression, but they inevitably meant that public debt went up. So the net effect was a long period of time in which corporate leverage slowly fell and public leverage relentlessly increased, with the total amount of debt to GDP, public and private combined, relentlessly increasing. What has happened after 2008 is simply a carbon copy, across the advanced economies, of what happened in Japan in the 1990s.

That is clearly shown by the latest figures just produced by the Bank for International Settlements, which show this rebalancing within the developed economies, with private debt moving to public debt. The total debt to GDP ratio of the advanced economies has continued to rise.

But there's also been a shift of debt across the world, because the other thing that's happened in the last 8 years is a huge increase in emerging market debt, particularly debt in China. That isn't just circumstantial. It isn't just, oh, well, there was a bit of a slowdown of the credit boom in the advanced economies, and, quite separately, China had an increase in credit. What went on, was that the Chinese were so worried that deleveraging in the advanced economies would drive their economy into recession in 2009, that they deliberately unleashed a huge credit boom.

So if we first allow private leverage to grow too high, we end up in a situation where the debt doesn't go away, it just moves around the global economy. Total global debt to global GDP is now higher than it ever was before. And that seems to leave us in a position where eventually all our policy levers are blocked, or have adverse side effects.

In the immediate aftermath of the crisis, we all, of course, agreed that what we should have is debt financed fiscal deficits. In April 2009, at the meeting of the G20 in London, it was agreed, everybody must run large deficits. Those deficits undoubtedly had a first round stimulative effect. If you want to understand why the U.S. has grown faster than the Eurozone over the last 9 years, it is essentially because it has run larger fiscal deficits as a percent of GDP. But, after a while, people begin to worry, oh, what are we going to do about long-term debt sustainability? Are these deficits going to work forever? Or is there something called Ricardian equivalence out there, where ordinary people will start worrying about long-term debt sustainability, so the deficits will be ineffective?

After a period of time of running these fiscal deficits, we all decided that there had to be a halt to that. We had to constrain the fiscal debt increase. But, hey, presto, we said that will be okay, because we could have ultra-loose monetary policy instead. 
I, however, simply don't believe that ultra-loose monetary policy is effective through the classic monetary policy transmission mechanisms. When interest rates are already low, further reductions of interest rates to still lower levels have very little influence on investment and consumption. Particularly if households and companies are already highly leveraged. I think there is little sign that ultra-loose monetary policy has worked through the interest rate elasticity of investment and consumption.

I think ultra-loose monetary policy does produce increases in asset prices. But if that's driving an increase in inequality on top of slow growth of real wages, then look out for some very strong populist political reaction. Now, of course, some people say, ah, no, ultra-loose monetary policy works through currency devaluation.

Well, it can work through currency devaluation for one economy within a strongly growing world economy. But if the whole world has a debt overhang problem, we cannot solve that problem by devaluing our currencies against those of Pluto, Mars, and Mercury. That is not an available strategy. At the end of the day, monetary policy only works by re-stimulating growth of private credit. Which is why in the spring last year, the front page of the Economist magazine was asking the question of whether we were simply "out of ammo?" Was there nothing more we could do to stimulate the world economy?

We seem to be stuck in a position where we end up with these unavoidable choices.

Either we have sustained low growth and low inflation, and debt burdens never decline. Or you say, well, we should do debt write-off, default, and restructuring. Maybe we should've done more of that back in 2009. But, actually, history tells us it's damn difficult to do debt default and restructuring on a big enough scale to solve the problem without that driving the economy into still deeper recession. After all, that was the strategy that we tried after the last great credit boom of the 1920s. That is the strategy which we used between '29 to ' 33 and it really didn't end very well, either in the U.S. or in continental Europe.

Or we simply accept that we've got ultra-low interest rates forever. But that will lead to new debt creation.

If that's the situation, that poses two questions for public policy. How to avoid getting into this mess in the first place and what do we do once we're in this situation? On the first, I think the most crucial theoretical point to understand is that different categories of credit creation perform quite different economic functions.

I think there has been inadequate focus in economics on the different functions that credit creation plays within the economy. If you finance investment, then you actually stimulate nominal demand and you allocate capital. But if you finance the purchase of existing assets, there is no necessary direct stimulus to nominal demand. You may stimulate demand via wealth effects and Tobin's $q$ effects. But those are indirect transmission mechanisms and they might take a hell of a long time to be have an effect.

And once you begin to think about the different impacts of different categories of credit, you realize that, whereas it's absolutely right to say that monetary aggregates matter, they matter for a completely different reason than monetarist theory assumed.

It is simply not the case empirically that excessive money creation is necessarily a good forward indicator of inflation. Quite often the problem is that excessive credit is an indicator of crisis, debt overhang, post-crisis depression, and deflation. So monetarist economists of the past were, I suggest, looking the wrong way on the wrong side of the bank balance sheets. That then has an implication for policy. I do not think we can drive the monetary economy and the economy of credit creation with one objective and one instrument. I do not think low and stable inflation is sufficient, because credit and asset price cycles and rising leverage can produce macroeconomic instability while never producing inflation.

Therefore we cannot just use the interest-rate tool. We cannot just use the interest-rate tool to constrain the credit cycle-because the demand for credit varies significantly by sector. Contrary to Wicksell, there is no one natural interest rate.

I therefore believe that we need to use much stronger macroprudential, quantitative, levers, such as limits to loan to value, countercyclical capital, and variation of risk weights, to control the credit cycle. I think we have to think about control of the credit cycle as an end, per se. That's what we should've been doing in the 1990s and 2000s in order not to get into the mess we got into.

But the second question is, how do we get out of it? Once you're in this mess, are you truly out of ammunition? And here I have ended up in a very radical point of viewwhich has shocked some of my colleagues. The first point I want to make is that actually insofar as we have got out of it, and America's closer to getting out of it than other countries what has got us out, as I said early, is fiscal stimulus.

If you want to understand why the global economy is looking considerably better this year than last, have a look at the fiscal stimulus which has been introduced in China. It always shocks me how little people pay attention to what is happening in the Chinese economy. This is now a \$13trillion economy. If they switch their fiscal deficit from $1 \%$ of GDP to $4 \%$ of GDP, that's a hell of a lot of demand going into the global economy. If that had not occurred, I think the global economy would now be growing much more slowly than it is.

But if you run these fiscal deficits, what are you going to do about the rising level of public debt? Is there a danger of 
Ricardian equivalence? Well, the answer is there isn't an absolute problem, because fiscal policy can always be lubricated by loose monetary policy.

I think the dirty little secret, the truth that dare not speak its name of what has been going on over the last 5 years, is that ultra-loose monetary policy has not been working through the transmission policy mechanism of monetary policy alone, it has been working because it has been lubricating fiscal deficits. It's been lubricating fiscal deficits by keeping interest rates low, however big the fiscal deficit. It's been lubricating fiscal deficits, because the Federal Reserve's been making a lot of money out of monetary easing, which it has been giving back to the federal government as a subsidy for the budget. It's been lubricating it, because people know that at the limit, this debt does not have to be repaid; that it could be permanently monetized.

One of the great papers over the last 2 years, which explored that, was Christopher Sims' paper at Jackson Hole last year. He said, "Fiscal expansion can replace ineffective monetary policy at the zero-lower bound, but it must be clear that the debt will be seen as financed by future inflation," or, I would say, monetization, "not future taxes or spending cuts."

I think that is in essence what has been going on, and why at last we have begun to come out of this recessionat least in the U.S., though less so elsewhere. Now, of course, some people in the past have been less ashamed about making this proposition. Ben Bernanke in Japan in 2003, faced with the Japanese deflationary problem said, why don't you consider, for example, "a tax cut for households and business explicitly coupled with incremental Bank of Japan purchases of government debt, so that the tax cut is in effect financed by money creation?"

Helicopter Ben. What a dangerous man he was. Except, of course, Milton Friedman said exactly the same in 1948. Under the proposal he then made, "Government expenditure would be financed entirely by tax revenues or the creation of money. The chief function of the monetary authority would be the creation of money to meet government deficits."

Maybe you'd like to ask Janet tomorrow whether she accepts that definition of her role.

I have set out in a paper, which I gave at the IMF Jacques Polak Research Conference in November 2015, my own version of the case for monetary finance. What I did there is argue that essentially the issues are political, not technical.

It is absolutely possible if you get in a deep inflationary trap to get out of it by overt monetary finance or, by what we've been doing so far, fiscal expansion lubricated by monetary expansion, which might turn into monetary finance at the end of the day, but we don't need to specify it now.
And in at least one country, there is certainly going to be permanent monetary finance. Look at the figures for Japan. Gross public debt is now stable at about $240 \%$ of GDP. Net debt on the IMF's standard definition is stable at about $120 \%$ of GDP. But those figures will never come down, I can assure you, by what we think is the normal process of Japan switching from a primary deficit to running a primary surplus and running down that debt. If the Japanese attempted to do so, they would tank the economy into a recession.

What is going on is that the percentage of GDP owned by the Bank of Japan is relentlessly rising. Hence, the percentage of the debt which is owned outside the Bank of Japan is relentlessly falling. At some stage, the Japanese people are going to realize that they don't really owe this debt, because they owe it to themselves.

In some circumstances, you do monetary finance, and there's nothing necessarily wrong with it. At the core of my book is a belief that we have to return to understanding two essential sources of nominal demand growth. One is private credit and money creation. The other is sovereign fiat money creation now, or expected in the future. This arises from fiscal expansion lubricated by money easing. Now our modern orthodoxy is that fiat money creation, those fiscal deficits lubricated by monetary policy are dangerous, because governments will go and do a Weimar, do a modern Zimbabwe. So it has to be totally controlled.

Our modern orthodoxy before the crisis was also that private credit and money creation is just fine, because it's governed by a free market which is bound to assure an optimal result. But it's interesting that not far from here over in Chicago, 80 years ago, some very fine economists ended up reaching exactly the diametrically opposite conclusion.

They believed that private credit and money creation was so dangerous that banks should be abolished. Which is why they proposed $100 \%$ reserve banking in the Chicago Plan presented to President Roosevelt in 1935. And they accepted that if you moved to $100 \%$ reserve banking, the only way you would then get an increase in aggregate nominal demand is what Friedman suggested in 1948, which was to run each year a small budget deficit, and always finance it by overt money creation.

I believe that both of those points of view are too extreme. We have to understand that both governments can fail and be dangerous, and that markets can fail and be dangerous. We have to find a way of navigating between both of those, understanding that we have to control private credit creation in the upswing, and that in the downswing, we may have to use extremely unconventional measures, but we have to place those within tight political disciplines as well. Which is why I believe we are stuck between debt and the devil. 
A famous figure from German literature is Mephistopheles, the devil in Goethe's Faust. Mephistopheles says to the emperor, "Emperor, you do not need to be constrained in your public expenditures by the ability to tax, because you can print as much money as you want." The reason why I called my book, Between Debt and the Devil, is that, in 2012, Jens Weidmann, the president of the Bundesbank, gave a speech in which he pretty much implied that Mario Draghi was beginning to grow a pair of horns, because Mario was beginning to suggest quantitative easing.

Jens said, "No. This is the work of the devil from Goethe's Faust and it will all end in hyper-inflation." I don't think it can be as simple as that. I think we have to realize that pure free market approaches to credit creation can produce disaster.

Pure sovereign approaches to creating demand, of course, can also produce disaster. We've seen that from history. We have to find a way which navigates between them, and create appropriate disciplines, both on what the private sector and what on the state does. We are stuck between debt and the devil. Thank you very much.

\section{Reference}

Reinhart, Carmen M, and Kenneth S. Rogoff. 2013. Financial and Sovereign Debt Crises: Some Lessons Learned and Those
Forgotten. IMF Working Paper WP/13/266. https://www.imf. org/external/pubs/ft/wp/2013/wp13266.pdf. Accessed 4 December 2017.

Lord Adair Turner is Chairman of the Institute for New Economic Thinking. Prior to joining the Institute in 2013, he chaired the UK Financial Services Authority (2008-2013) and played a leading role in the redesign of the global banking and shadow banking regulation as Chairman of the International Financial Stability Board's major policy committee. He has combined a business career with public policy and academia. He was at McKinsey from 1982 to 1995, building their practice in East Europe and Russia; was Director General of the CBI (Confederation of British Industry) 1995-2000; became Vice-Chairman of Merrill Lynch Europe (2000-2006); and has been a Non-Executive Director of a number of companies, including Standard Chartered plc (2006-2008). Currently, he is a nonExecutive Director at Prudential plc., and Chairman of CHUBB Europe. He is also chairing the Energy Transitions Commission, and is a Trustee of the British Museum. A cross-bench member of the House of Lords since 2005, he served as the first Chairman of the Climate Change Committee (2008-2012); chaired the Pensions Commission (2003-2006) and the Low Pay Commission (2002-2006). His latest book, Between Debt and the Devil, was published by Princeton in 2015 and has been translated into Chinese, Japanese, Korean, French, and Portuguese; other publications include 'Just Capital-The Liberal Economy' (2001); 'Economics After the Crisis' (2012). He is Senior Fellow at the Centre for Financial Studies (Frankfurt), and a visiting professor at the London School of Economics and at Cass Business School. More recently, he has been appointed Visiting Fellow at the People's Bank of China School of Finance, Tsinghua University (Beijing) and Visiting Professor at the International Center for Islamic Finance (INCEIF) in Kuala Lumpur. He was elected an Honorary Fellow of the Royal Society in 2016. 